Олійник О. О. ${ }^{[1 ;}$ ORCID ID:0000-0002-3941-2286], к.е.н., доцент,

Пожарський Д. С. [1; ORCID ID: 0000-0001-7009-8275], здобувач вищої освіти першого (бакалаврського) рівня,

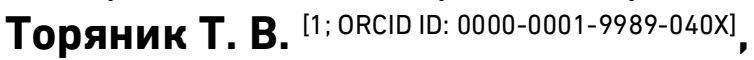
здобувач вищої освіти першого (бакалаврського) рівня

${ }^{1}$ Національний університет водного господарства та природокористування, м. Рівне

\title{
ІНТЕЛЕКТУАЛЬНА МІГРАЦІЯ: СУТНІСНІ ХАРАКТЕРИСТИКИ ТА ВПЛИВ НА ЕКОНОМІЧНЕ ЗРОСТАННЯ КРАЇНИ
}

В статті досліджено сутність поняття «інтелектуальна міграція» та суміжних термінів. Проаналізовано вплив міграції висококваліфікованих працівників на економічне зростання країни. За результатами кореляційного аналізу визначено, що привабливість країни для талантів суттєво та сильно впливає її на економічне зростання.

Ключові слова: міграція; знання; інтелектуальна міграція; населення; відтік мізків; приріст мізків.

Постановка проблеми. У сучасній глобальній економіці знання $€$ найважливішим рушієм продуктивності та економічного зростання, забезпечуючи стійку конкурентоспроможність та впровадження інновацій. Важливим інструментом отримання та передачі знань $€$ зовнішня міграція, масштаби якої набувають все більшого поширення на теренах усіх країн. Статистичні дані констатують наявність у 2020 році у світі близько 281 мільйонів міжнародних мігрантів, що дорівнює 3,6 відсотка світового населення. При цьому за останні п'ять десятиліть приблизна кількість міжнародних мігрантів зросла. Загалом, у 2020 році 281 мільйон людей, які проживають у країні, що не є країною їх народження, було на 128 мільйонів людей, які проживають у країні, що не $є$ країною їх народження, більше, чим у 1990 році, і це втричі перевищувало кількість мігрантів у 1970 році [1]. Третину частину з усіх мігрантів становлять люди з вищою освітою, тобто так звані інтелектуальні мігранти. За таких умов виникає необхідність в дослідженні сутнісних характеристик інтелектуальної міграції та визначення їі впливу на економічне зростання країни задля формування ефективних управлінських заходів на різних ієрархічних рівнях. 
Аналіз останніх досліджень та публікацій. Дослідженню проблематики трудової міграції висококваліфікованих працівників присвячені роботи багатьох вчених, зокрема: Т. Алексєєвої, С. Гринкевич, Л. Давидюк, Б. Кузьменка, О, Кваші, К. Левчук, К. Ніколаєць, У. Садової, А. Соломко, А. Тімофєєва, К. Шиманської та ін. Однак, незважаючи на суттєву увагу науковців до вивчення проблематики зовнішньої міграції, формування ефективної системи регуляторних заходів щодо високоосвічених мігрантів не набуло широкого поширення в практичній діяльності органів державної влади різних рівнів. За таких умов дослідження особливостей інтелектуальної міграції $€$ актуальним науковим завданням.

Метою роботи є дослідження впливу інтелектуальної міграції на економічне зростання країни.

Виклад основного матеріалу. Передача знань визначається як багатоетапний процес, який включає передачу інформації однією особою чи групою та поглинання зазначеної інформації іншою особою чи групою. При цьому цінність знань проявляється в їхньому впливі на поведінку, політику, процеси та практику діяльності сторони-одержувача. Мігранти можуть принести важливі знання до країни призначення, оскільки часто володіють додатковими навичками та інноваційними ідеями, що сприяють покращенню ефективності бізнес-процесів та підвищенню продуктивності. Мігранти також можуть привнести певні культурні знання, цінності та поведінку, які називаються «м'якими знаннями» [2]. Цінність знань мігрантів часто полягає в дефіциті цих знань у країні призначення, адже глобальний дефіцит талантів в епоху формування економіки знань постійно зростає: $69 \%$ роботодавців відчувають труднощі 3 заповненням робочих місць (рис. 1).

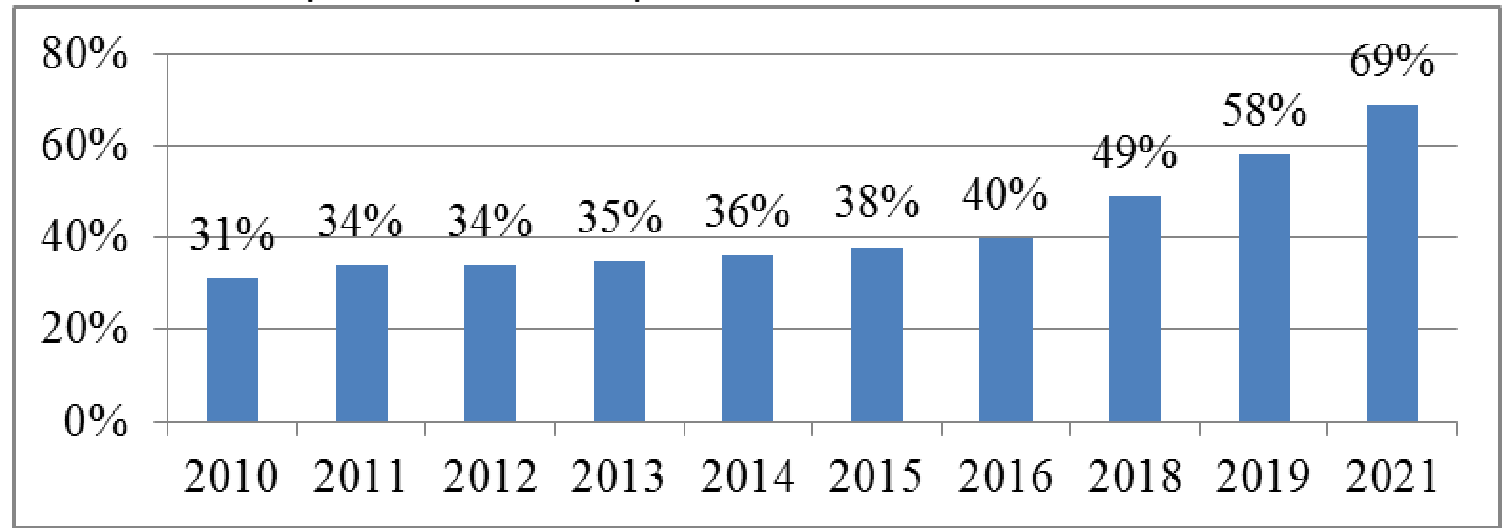

Рис. 1. Дефіцит талантів в світі

Джерело: складено за даними [3] 
Незважаючи на постійне зростання обсягів міграційних потоків, на сьогодні відсутній єдиний підхід до визначення сутності категорії «інтелектуальна міграція». Однак спільною ознакою $\epsilon$ те, що невід'ємною частиною цієї категорії $€$ міграція вчених, інженерів, фахівців у галузях науки і техніки, представників творчої інтелігенції, а також бізнес-еліт та підприємницької спільноти (так звана «елітна міграція»). Розширене тлумачення включає весь комплекс міграційних потоків кваліфікованих і висококваліфікованих працівників, які здійснюють трудову діяльність за кордоном понад один рік. Це міжнародна міграція наукових і викладацьких кадрів високої і вищої кваліфікації, які реально або потенційно займаються науковими дослідженнями і розробками та обслуговуванням такої діяльності [4].

Інтелектуальна міграція - це одна із форм міграційної поведінки, пов'язана 3 рішенням представників висококваліфікованої розумової праці мігрувати з однієї країни до іншої і залишитись в ній; це односторонній процес відтоку (реального чи віртуального) працівника інтелектуальної праці з країни-донора, що означатиме для останньої невідновлювальні втрати здійснених інвестицій в інтелектуальний капітал і втрату потенційних доходів. Зовнішня «інтелектуальна міграція» обумовлена незадоволеністю особи заробітками та можливостями творчого самовираження в країні походження і прагненням вирішення даних проблем в країніреципієнті [5].

Варто зауважити, що сучасна українська та зарубіжна наукова спільнота поруч із терміном «інтелектуальна міграція» використовує також широке різноманіття суміжних категорій (табл. 1)

Таблиця 1

Терміни в царині інтелектуальної міграції

\begin{tabular}{|l|l|l|}
\hline $\begin{array}{c}\text { Термін } \\
\text { українською } \\
\text { мовою }\end{array}$ & $\begin{array}{c}\text { Термін } \\
\text { англійською } \\
\text { мовою }\end{array}$ & \multicolumn{1}{|c|}{ Характеристика } \\
\hline відплив мізків & brain drain & $\begin{array}{l}\text { виїзд значної кількості фахівців, що має } \\
\text { економічні наслідки }\end{array}$ \\
\hline набуття мізків & brain gain & $\begin{array}{l}\text { прибутт кваліфікованих іммігрантів, що } \\
\text { прскорює розвиток економіки }\end{array}$ \\
\hline $\begin{array}{l}\text { циркуляція } \\
\text { мізків }\end{array}$ & $\begin{array}{l}\text { brain } \\
\text { сirculation }\end{array}$ & $\begin{array}{l}\text { періодичні виїзи/повернення } \\
\text { висококваліфікованих фахівців, однаково } \\
\text { заангажованиху наукових дослідженнях чи } \\
\text { високотехнологічних виробництвах в обох } \\
\text { країнах }\end{array}$ \\
\hline
\end{tabular}


продовження табл. 1

\begin{tabular}{|c|c|c|}
\hline $\begin{array}{l}\text { розтікання/ } \\
\text { поширення } \\
\text { мізків }\end{array}$ & brain strain & $\begin{array}{l}\text { глобальне поширення знань завдяки } \\
\text { міграції фахівців та студентів }\end{array}$ \\
\hline $\begin{array}{l}\text { повернення } \\
\text { мізків }\end{array}$ & reverse brain & $\begin{array}{l}\text { повернення спеціалістів, збагачених } \\
\text { іноземним досвідом для постійної або й } \\
\text { тимчасової роботи на батьківщині, а також } \\
\text { участь у проєктах на батьківщині } \\
\text { віртуально, без фізичного повернення }\end{array}$ \\
\hline втрата мізків & brair & $\begin{array}{l}\text { кваліфіковані мігранти за кордоном } \\
\text { виконують некваліфіковану } \\
\text { втрачають професійні навички }\end{array}$ \\
\hline заміна мізків & $\begin{array}{l}\text { brain } \\
\text { exchange }\end{array}$ & $\begin{array}{l}\text { заміщення фахівців, які виїжджають за } \\
\text { кордон, спеціалістами, які прибули з інших } \\
\text { країн }\end{array}$ \\
\hline $\begin{array}{l}\text { глобалізація } \\
\text { мізків }\end{array}$ & $\begin{array}{l}\text { brain } \\
\text { globalization }\end{array}$ & $\begin{array}{l}\text { певний рівень мобільності професіоналів, } \\
\text { необхідний для участі у глобальній } \\
\text { економіці }\end{array}$ \\
\hline експорт мізків & brain export & $\begin{array}{l}\text { цілеспрямована підготовка спеціалістів для } \\
\text { роботи за кордоном } 3 \text { метою отримання } \\
\text { економічних вигод }\end{array}$ \\
\hline
\end{tabular}

Джерело: складено за даними [6]

Організація економічного співробітництва та розвитку (ОЕСР) вважає, що талановиті та кваліфіковані люди відіграють ключову роль у майбутньому процвітанні країн. Вони займають робочі місця, які $\epsilon$ ключовими для інновацій та технологічного прогресу i, врештірешт, сприяють посиленню економічного зростання разом з іншими можливостями працевлаштування та кращими умовами життя для всіх. За таких умов країни ОЕСР все більше конкурують у залученні та утриманні талановитих працівників, зокрема шляхом прийняття більш сприятливої міграційної політики для найкращих та найяскравіших талантів. Задля оцінювання успішності в такій конкурентній боротьбі розраховується показник привабливості талантів ОЕСР - це перший комплексний інструмент для виявлення сильних та слабких сторін країн ОЕСР щодо їхньої здатності залучати та утримувати три конкретні категорії талановитих мігрантів: високоосвічених працівників (магістрів та докторів наук), іноземних підприємців та студентів університетів [7].

Задля визначення зв'язку між показником привабливості високоосвічених працівників (магістрів та докторів наук) та економічним зростанням країни, базовим показником оцінювання 
кого $€$ валовий національний дохід на душу населення, авторами було проведено кореляційний аналіз на основі даних 20 країн ОЕСР за 2019 р. (табл. 2).

Таблиця 2

Результати кореляційного аналізу зв'язку показника привабливості талантів та ВНД на душу населення

\begin{tabular}{|l|l|c|c|}
\hline $\begin{array}{c}|c| \\
\text { № }\end{array}$ Країна & \multicolumn{1}{|c|}{$\mathrm{y}$} & $\mathrm{X}$ \\
\hline 1. & Австралія & 54910 & 0,63 \\
\hline 2. & Австрія & 51300 & 0,54 \\
\hline 3. & Бельгія & 47350 & 0,53 \\
\hline 4. & Канада & 46370 & 0,61 \\
\hline 5. & Чилі & 15010 & 0,46 \\
\hline 6. & Чехія & 22000 & 0,51 \\
\hline 7. & Данія & 63240 & 0,57 \\
\hline 8. & Фінляндія & 49580 & 0,54 \\
\hline 9. & Німеччина & 48520 & 0,57 \\
\hline 10. & Греція & 20320 & 0,4 \\
\hline 11. & Угорщина & 16140 & 0,49 \\
\hline 12. & Латвія & 17730 & 0,46 \\
\hline 13. & Люксембург & 73910 & 0,58 \\
\hline 14. & Мехіко & 9430 & 0,38 \\
\hline 15. & Норвегія & 82500 & 0,58 \\
\hline 16. & Швеція & 55840 & 0,63 \\
\hline 17. & Швейцарія & 85500 & 0,62 \\
\hline 18. & Туреччина & 9610 & 0,35 \\
\hline 19. & Великобританія & 42370 & 0,55 \\
\hline 20. & США & 65760 & 0,59 \\
\hline 21. & & & 0,838 \\
\hline
\end{tabular}

Джерело: розраховано за даними [7; 8]

Результати кореляційного аналізу дозволяють стверджувати, що показник привабливості талантів суттєво та сильно впливає на економічне зростання країни. При цьому зв'язок між даними показниками є прямим: із зростанням привабливості країни для приїзду висококваліфікованих працівників ВНД на душу населення 86 
збільшується. Розрахований коефіцієнт парної кореляції $\epsilon$ статистично значимим, оскільки фактичне значення критерія Стюдента $(6,528)$ перевищує критичне значення $(2,315)$.

За таких умов економічно розвинені країни усіляко сприяють залученості висококваліфікованих мігрантів. При цьому дослідження показують, що інтелектуальна міграція викликана більшою мірою дією чинників «тяжіння» в приймаючих країнах, чим чинниками «виштовхування» 3 країн-донорів висококваліфікованої робочої сили. Відтак розвинені країни формують цілеспрямовану політику із залучення працівників вищої кваліфікації, передусім наукових працівників, створюючи гнучкі та сприятливі програми. Традиційно лідером у багатьох галузях науки є США і вони залишаються загальносвітовим центром тяжіння висококваліфікованих фахівців [9].

Висновки. Таким чином, результати проведеного дослідження підтверджують тісний та прямий зв'язок між інтелектуальною міграцією та економічним зростанням країни. Відтак, урядам задля посилення конкурентоспроможності своїх країн та економічного процвітання необхідно різноманітними методами стимулювати залучення висококваліфікованих мігрантів. Приїзд висококваліфікованих мігрантів поповнює інтелектуальний капітал країн-реципієнтів. Водночас тим самим створюється позитивне конкурентне середовище для місцевих спеціалістів, чим посилюється мотивація останніх вчитися впродовж усього життя, постійно підвищуючи кваліфікацію та здобуваючи нові компетенції.

1. World Migration Report 2020. International Organization for Migration. URL: https://publications.iom.int/system/files/pdf/wmr_2020.pdf (дата звернення: 07.09.2021). 2. Mueller Ch. Migration \& knowledge transfer. NVVN. URL: https://nvvn.nl/migration-knowledge-transfer/ (дата звернення: 07.09.2021). 3. Manpower Group Employment Outlook Survey Q3 2021. Global Results. Manpower Group.

URL: https://go.manpowergroup.com/hubfs/Talent\%20Shortage\%202021/MPG_2021_Outlo ok_Survey-Global.pdf (дата звернення: 07.09.2021). 4. Островський І. А., Рибак Г. І. Освітні аспекти міжнародної інтелектуальної міграції. Науковий вісник Ужгородського національного університету. 2019. Вип. 25. С. 42-45. 5. Давидюк Л. П. Інтелектуальна міграція трудових ресурсів в умовах глобалізації. Ефективна економіка. 2019. URL: http://www.economy.nayka.com.ua/pdf/11_2019/71.pdf (дата звернення: 07.09.2021). 6. Малиновська О. А. Міграційна політика: глобальний контекст та українські реалії : монографія. НІСД, 2018. 472 с. 7. Talent Attractiveness. OECD. URL: https://www.oecd.org/migration/talent-attractiveness/ (дата звернення: 07.09.2021). 8. World Development Indicators database. World Bank. URL: https://databank.worldbank.org/data/download/GNIPC.pdf (дата звернення: 07.09.2021). 9. Власова Т. Р. Міжнародна інтелектуальна міграція: від «відпливу умів» до їх циркуляції. Демографія, економіка праці, соціальна економіка та політика. 2020. Вип. 1-2. С. 315-325. 
Серія «Економічні науки»

Випуск 3(95) 2021 р.

\section{REFERENCES:}

1. World Migration Report 2020. International Organization for Migration. URL: https://publications.iom.int/system/files/pdf/wmr_2020.pdf (data zvernennia: 07.09.2021). 2. Mueller Ch. Migration \& knowledge transfer. NVVN. URL: https://nvvn.nl/migration-knowledge-transfer/ (data zvernennia: 07.09.2021). 3. Manpower Group Employment Outlook Survey Q3 2021. Global Results. Manpower Group.

URL: https://go.manpowergroup.com/hubfs/Talent\%20Shortage\%202021/MPG_2021_Outlo ok_Survey-Global.pdf (data zvernennia: 07.09.2021). 4. Ostrovskyi I. A., Rybak H. I. Osvitni aspekty mizhnarodnoi intelektualnoi mihratsii. Naukovyi visnyk Uzhhorodskoho natsionalnoho universytetu. 2019. Vyp. 25. S. 42-45. 5. Davydiuk L. P. Intelektualna mihratsiia trudovykh resursiv v umovakh hlobalizatsii. Efektyvna ekonomika. 2019. URL: http://www.economy.nayka.com.ua/pdf/11_2019/71.pdf (data zvernennia: 07.09.2021). 6. Malynovska 0. A. Mihratsiina polityka: hlobalnyi kontekst ta ukrainski realii : monohrafiia. NISD, 2018. 472 s. 7. Talent Attractiveness. OECD. URL: https://www.oecd.org/migration/talent-attractiveness/ (data zvernennia: 07.09.2021). 8. World Development Indicators database. World Bank. URL: https://databank.worldbank.org/data/download/GNIPC.pdf (data zvernennia: 07.09.2021). 9. Vlasova T. R. Mizhnarodna intelektualna mihratsiia: vid «vidplyvu umiv» do yikh tsyrkuliatsii. Demohrafiia, ekonomika pratsi, sotsialna ekonomika ta polityka. 2020. Vyp. 1-2. S. 315-325.

\section{Oliinyk 0. 0. [1; ORCID ID: 0000-0002-3941-2286], Candidate of Economics (Ph.D.), Associate Professor, Pozharskyi D. S. [1; ORCID ID: 0000-0001-7009-8275],} Senior Student, Torianyk T. V. [1; ORCID ID: 0000-0001-9989-040X] Senior Student

${ }^{1}$ National University of Water and Environmental Engineering, Rivne

\section{INTELLECTUAL MIGRATION: ESSENTIAL CHARACTERISTICS AND IMPACT ON THE COUNTRY'S ECONOMIC GROWTH}

The article investigates the essence of the concept of «intellectual migration». An important factor in the spread of intellectual migration is the global shortage of talent in the era of the knowledge economy. Related terms in the field of intellectual migration are analyzed: brain drain, brain growth, brain circulation, brain loss, brain return, brain replacement. Migrants can bring important knowledge to their destination country, as they often have additional skills and innovative ideas that help improve business processes and increase productivity. It is determined that economically developed countries are increasingly competing in attracting and retaining talented workers, in particular by adopting a more favorable migration 88 
policy for the best and brightest talents. To determine the relationship between the attractiveness of highly educated workers and economic growth, the basic indicator of estimating who is the gross national income per capita, the authors conducted a correlation analysis based on data from 20 OECD countries in 2019. The relationship between these indicators is close and direct: as the country's attractiveness for the arrival of highly skilled workers increases, the gross national income per capita increases. Economically developed countries contribute to the attraction of highly qualified migrants. At the same time, studies show that intellectual migration is caused more by «gravity» factors in host countries than by «push» factors from highly skilled labor donor countries. Therefore, to strengthen the competitiveness of their countries and economic prosperity, governments need to use various methods to stimulate the involvement of highly qualified migrants. The arrival of highly qualified migrants replenishes the intellectual capital of the recipient countries.

Keywords: migration; knowledge; intellectual migration; population; brain drain; brain growth.

Олейник Е. А. [1; ORCID ID: 0000-0002-3941-2286], К.э.н., доцент,

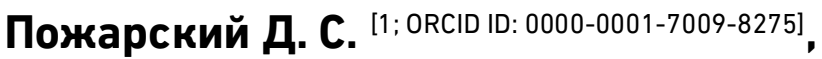
соискатель высшего образования первого (бакалаврского) уровня,

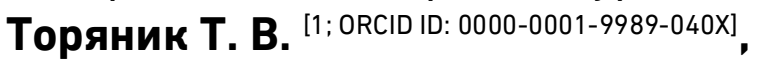
соискатель высшего образования первого (бакалаврского) уровня

${ }^{1}$ Национальный университет водного хозяйства и природопользования, г. Ровно

\section{ИНТЕЛЛЕКТУАЛЬНАЯ МИГРАЦИЯ: СУЩНОСТНЫЕ ХАРАКТЕРИСТИКИ И ВЛИЯНИЕ НА ЭКОНОМИЧЕСКИЙ РОСТ СТРАНЫ}

В статье исследована сущность понятия «интеллектуальная миграция» и смежных терминов. Проанализировано влияние миграции высококвалифицированных работников на экономический рост страны. По результатам корреляционного анализа определено, что привлекательность страны для талантов существенно и сильно влияет ее на экономический рост.

Ключевые слова: миграция; знания; интеллектуальная миграция; население; отток мозгов; прирост мозгов.

Отримано: 14 вересня 2021 р. Прорецензовано: 17 вересня 2021 р. Прийнято до друку: 24 вересня 2021 р. 